Article

\title{
The Evaluation of Growth Performance, Photosynthetic Capacity, and Primary and Secondary Metabolite Content of Leaf Lettuce Grown under Limited Irradiation of Blue and Red LED Light in an Urban Plant Factory
}

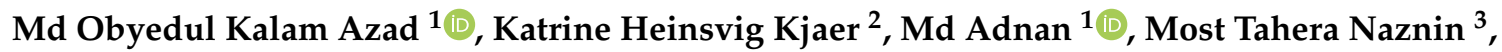 \\ Jung Dae Lim ${ }^{4}{ }^{\mathbb{D}}$, In Je Sung ${ }^{1}$, Cheol Ho Park ${ }^{1}$ and Young Seok Lim ${ }^{1, *}$ \\ 1 Department of Bio-Health Technology, College of Biomedical Science, Kangwon National University, \\ Chuncheon 24341, Korea; azadokalam@gmail.com (M.O.K.A.); mdadnan1991.pharma@gmail.com (M.A.); \\ Koreaginseng@daum.net (I.J.S.); chpark@kangwon.ac.kr (C.H.P.) \\ 2 Danish Technological Institute, Gregersensvej 7, DK-2630 Taastrup, Denmark; kkja@teknologisk.dk \\ 3 Department of Biosystems and Technology, Swedish University of Agricultural Sciences, Box 103, \\ 23053 Alnarp, Sweden; naznin.most.tahera@slu.se \\ 4 Department of Herbal Medicine Resource, Kangwon National University, Samcheok 25949, Korea; \\ ijdae@kangwon.ac.kr \\ * Correspondence: potatoschool@kangwon.ac.kr; Tel.: +82-33-250-6474
}

Received: 17 December 2019; Accepted: 19 January 2020; Published: 21 January 2020

\begin{abstract}
Plant production in urban areas is receiving much attention due to its potential role in feeding the rapidly growing population of city dwellers. However, higher energy demands in urban plant factories are among the key challenges that need to be addressed. Artificial lighting is responsible for the most significant levels of energy consumption in plant factories; therefore, lighting systems must be modulated in consideration of the sustainable food-energy nexus. In this context, low light irradiation using blue (B) and red (R) LED was applied in a plant factory for the growth of red leaf lettuce (Lactuca sativa $\mathrm{L}$. var Lollo rosso) to evaluate the growth performance and functional quality. The tested $B(450 \mathrm{~nm})$ and $\mathrm{R}(660 \mathrm{~nm})$ light ratios were $B / R=5: 1 ; 3: 1 ; 1: 1 ; 1: 3$, and 1:5, with a photosynthetic photon flux density (PPFD) of $90 \pm 3 \mu \mathrm{mol} \mathrm{m}^{-2} \mathrm{~s}^{-1}$. In the plant factory, the photoperiod, temperature, $\mathrm{RH}$, and $\mathrm{CO}_{2}$ conditions were $16 \mathrm{~h} \mathrm{~d}^{-1}, 20 \pm 0.5^{\circ} \mathrm{C}, 65 \% \pm 5 \%$, and $360 \pm 10 \mu \mathrm{L} \mathrm{L}^{-1}$, respectively. The lettuce was harvested 10 and 20 days after the commencement of LED light treatment (DAT). In this study, normal photosynthetic activity and good visual quality of the lettuce were observed. The results show that a higher fraction of $R(B / R=1: 5)$ significantly increased plant growth parameters such as plant height, leaf area, specific leaf area, plant fresh and dry weight, and carbohydrate content. By contrast, a higher fraction of $B(B / R=5: 1)$ significantly increased the photosynthetic parameters and contents of pigment and phenolic compounds. The rate of photosynthetic performance, carbohydrates (except starch), and content of phenolic compounds were highest after $10 \mathrm{DAT}$, whereas the pigment contents did not significantly differ at the different growth stages. It is concluded that high $\mathrm{R}$ fractions favor plant growth and carbohydrate content, while high B fractions favor photosynthetic performance and the accumulation of pigments and phenolic compounds in red leaf lettuce under limited lighting conditions. This study will help in designing artificial lighting conditions for plant factory production to reduce energy demands.
\end{abstract}

Keywords: growth characteristics; photosynthesis; carbohydrate; pigments; phenolic compounds; leaf lettuce; plant factory 


\section{Introduction}

Artificial light emitting diodes (LED) have been strategically used for several decades in plant food production in urban plant factories to grow customized functional food. However, the major obstacle for growing plants in a plant factory is the high energy requirements. Therefore, the selection of low-light-adapted plant species and the reduction of energy costs are crucially important in achieving a sustainable urban food supply. In plant factories, most of the energy is consumed by the light sources, heating/cooling, and pump motors for nutrient supply; among these elements, $75 \%$ of the energy is consumed by artificial lighting [1]. To reduce light irradiation without hampering plant growth performance represents one of the vital strategies by which to reduce the energy costs of plant factories.

Lettuce is the best-suited candidate crop species to grow in a plant factory due to its low light adaptability. Lettuce leaves are considered as a highly nutritious food source, providing all the recommended macro- and micronutrients for a healthy diet [2]. The nutritional constituents and bioactive compounds of lettuce are customized through the tuning of environmental factors such as light irradiation, light spectra, temperature, relative humidity, and $\mathrm{CO}_{2}[3,4]$.

It has been observed that a customized artificial LED light spectrum has a positive effect on enhancing plant growth in a controlled environment. In the artificial light spectrum, blue (B) (420-450 nm) and red (R) (600-700 nm) light and their combinations are the most operative in terms of encouraging plant growth and development, and in influencing their architecture [5-7]. It has previously been reported that considering the total light that plants receive from natural sunlight, $90 \%$ of the absorbed light is B and R light [8]. Monochromatic light alone cannot meet the light energy demands for optimal plant growth [9]. B light is associated with physiological responses such as plant phototropism and stomatal opening, and is also absorbed by pigments, thus initiating the photosynthetic process. By contrast, R light regulates photomorphogenesis, energy distribution, and the photosynthetic apparatus $[10,11]$. Studies show that the phytochemical accumulation in vegetables is affected by genotype and environmental factors, including light [12]. Subsequent studies have shown that the ratio of $\mathrm{B}$ and $\mathrm{R}$ light is crucial for the accumulation of pigments and phenolic compounds in plants grown in a closed environment $[13,14]$. Extensive research has been carried out to evaluate the effect of $\mathrm{B} / \mathrm{R}$ light ratios on lettuce plant growth and development, and has proven to be a useful lighting source for producing many plant species in a controlled environment [15-17].

The light spectrum and intensity are the main crucial triggers for plant growth and development; however, light intensity plays a significant role in stimulating the biosynthesis of secondary metabolites [18]. Previously, Urrestarazu et al. [19] stated that leaf lettuce showed high energy efficiency and sufficient morphological response when grown under very low light (e.g., $85 \mu \mathrm{mol} \mathrm{m}{ }^{-2}$ $\mathrm{s}^{-1}$ ) irradiation; therefore, lettuce may be considered a low-light-adapted crop species [20]. A recent report by Rouphael et al. [21] stated that lettuce growth parameters were accelerated when grown under more intense light $\left(420 \mu \mathrm{mol} \mathrm{m} \mathrm{m}^{-2} \mathrm{~s}^{-1}\right)$ compared to lower light irradiation $\left(210 \mu \mathrm{mol} \mathrm{m} \mathrm{m}^{-2} \mathrm{~s}^{-1}\right)$, and, at the same time, that bioactive compounds and mineral contents were increased under lower light irradiation compared to higher levels. Under a low light regime, the plant tends to accumulate micronutrients in its sink, resulting in lower plant growth rates as well as lower biomass accumulation.

Plant production in plant factories under different combinations of BR light under a higher light regime has been well studied, and extensive research reports have already been published [15,21]. However, achieving a sustainable food-energy nexus through the reduction of lighting energy expenses by using low levels of light irradiation while maintaining effective production is of great interest for urban plant factory systems [22]. Previously, very low levels of LED light irradiation were applied to successfully grow leaf lettuce [19]; however, the B and R light ratios need to be optimized in order to determine the lowest effective intensity.

On a larger scale, plant factories typically produce more plants per unit area compared to conventional field cultivation; however, energy consumption is higher in the former. Therefore, the optimization of customized proprieties for plant production is a decisive strategy by which to improve the efficiency of resource use [23]. Moreover, many research strategies are being developed to grow 
plant foods in extreme environments, such as in the arctic region and even space farming [24]. Given these backgrounds, the design and development of species-specific factors is a crucial in establishing the sustainability of food-energy nexus. Artificial LED provides a means by which to control the light intensity according to precise spectrum with lower energy demand. The required electricity demand per $\mathrm{kg}$ vegetable production is approximately $10-17.5 \mathrm{~kW} \cdot \mathrm{h} / \mathrm{kg}$ in plant factories $[22,25]$. This electricity consumption could be reduced by decreasing the lighting quantity per unit area and shortening the photoperiod in a plant factory [26].

Artificial LED lighting has the capability to regulate the light quality and quantity, thus enabling the required lighting for a precise crop according to its developmental stage [27]. It is hypothesized that an optimal combination of $\mathrm{B} / \mathrm{R}$ light under low light irradiation will improve plant production while reducing energy expenses. Therefore, the objective of this study was to determine the optimal $\mathrm{B} / \mathrm{R}$ light ratios under a low light regime by assessing growth characteristics, net photosynthetic rate, stomatal conductance, chlorophyll fluorescence, carbohydrates, pigments, and phenolic contents in leaf lettuce cultured in a plant factory toward achieving sustainability in urban food production systems.

\section{Materials and Methods}

\subsection{Plant Materials and Growth Conditions}

Seeds of red leaf lettuce (Lactuca sativa L. var Lollo rosso) were sown in a 60-cell substrate plug tray 'Ellepress' (Ellegaard A/S, Viborg, Denmark) and placed in a climate chamber. The photosynthetic photon flux density (PPFD) in the climate chamber was $150 \pm 5 \mu \mathrm{mol} \mathrm{m}^{-2} \mathrm{~s}^{-1}$ at the plant canopy level (30 $\mathrm{cm}$ from the light source) from LED lamps with a B/R ratio of 3:5 (Green Power LED Production module deep red/blue 150. Philips, Pila, Poland). During lettuce seedling production, the PPFD was fixed at $150 \pm 5 \mu \mathrm{mol} \mathrm{m} \mathrm{m}^{-2} \mathrm{~s}^{-1}$ as this intensity corresponds to what is used in commercial practice and has been demonstrated as the ideal irradiation for obtaining viable lettuce seedlings. Other environmental factors of the climate chamber such as temperature, photoperiod, and relative humidity were maintained at $20 \pm 0.5{ }^{\circ} \mathrm{C}, 16 \mathrm{~h} / \mathrm{d}$, and $75 \% \pm 5 \% \mathrm{RH}$, respectively.

After growing for 15 days, the seedlings were moved to the plant factory equipped with artificial B and R LED light. A plate type B and R light emitting diode (LED) light (APL 0018-A, Stanley Electric Co., Ltd., Tokyo, Japan) was used as a sole lighting source. The spectral energy distribution of B (peak at $450 \mathrm{~nm}$ ) and R (peak at $660 \mathrm{~nm}$ ) LED lights were determined using a calibrated spectrometer (Jazz, Ocean Optics Inc., Florida, USA). Five different B/R light ratios were adjusted for this study, namely, $\mathrm{B} / \mathrm{R}=5: 1 ; 3: 1 ; 1: 1 ; 1: 3$, and 1:5 (Figure 1). The photosynthetic photon flux density (PPFD), photoperiod, temperature, and relative humidity were maintained and monitored at $90 \pm 3 \mu \mathrm{mol} \mathrm{m}^{-2} \mathrm{~s}^{-1}, 16 \mathrm{~h}$ $\mathrm{d}^{-1}, 20 \pm 0.5^{\circ} \mathrm{C}$, and $65 \% \pm 5 \%$, respectively, at the plant canopy level ( $35 \mathrm{~cm}$ below the light panel). The lettuce was harvested 10 and 20 days after the onset of LED light treatment (DAT). Plants were watered as required using the ebb and flow method with a nutrient solution.

\subsection{Leaf Photosynthesis and Chlorophyll Fluorescence}

The net photosynthetic rate $\left(\mathrm{P}_{\mathrm{n}}\right)$ and stomatal conductance $\left(\mathrm{g}_{\mathrm{s}}\right)$ were measured on well-developed leaves (third leaf from the top) for six plants under each treatment using an open system infrared gas analyzer (CIRAS-2, PP Systems, Hitchin, Herts, UK) with a PLC6 (U) Automatic Universal Leaf Cuvette $\left(1.7 \mathrm{~cm}^{2}\right)$. The measuring conditions were as follows: $400 \mu \mathrm{mol} \mathrm{mol}^{-1} \mathrm{CO}_{2}$, airflow $200 \mathrm{~mL}$ $\mathrm{min}^{-1}$, temperature $20 \pm 1{ }^{\circ} \mathrm{C}$, vapor pressure deficit (VPD) $10 \pm 3 \mathrm{mbar}$, and $50 \% \pm 10 \% \mathrm{RH}$ during measurement. The maximum photochemical efficiency of PSII $\left(\mathrm{F}_{\mathrm{v}} / \mathrm{F}_{\mathrm{m}}\right)$ was measured on fully expanded leaves (second/third leaf from the top) with a miniaturized pulse-amplitude-modulated photosynthesis yield analyzer, MINI-PAM (Walz, Effeltrich, Germany). Before measuring the chlorophyll fluorescence, the selected leaves were adapted in the dark for $30 \mathrm{~min}$ by leaf clips (DLC-8, Walz, Effeltrich, Germany) to obtain the maximum oxidized state of PSII-PSI electron transport carriers. The $F_{\mathrm{v}} / \mathrm{F}_{\mathrm{m}}$ was calculated according to Maxwell and Johnson [28]. 

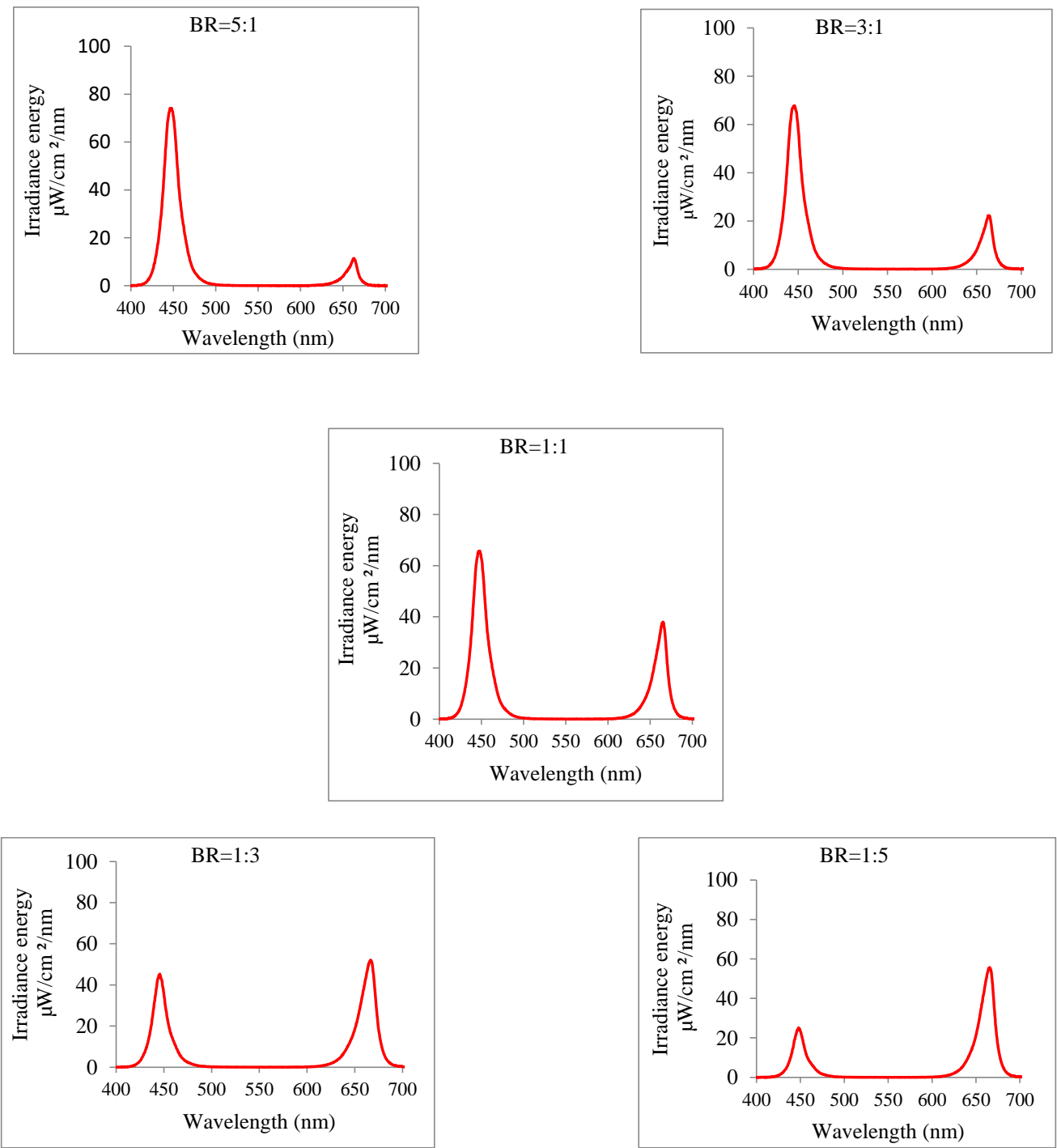

Figure 1. Spectral photon flux energy distribution of different blue (B)/red (R) light ratios.

\subsection{Growth Analysis}

Ten plants from each treatment were selected for growth analysis. Plant height was measured from base to shoot tip using a ruler, and the leaf number was counted. Plant fresh weight (FW) and dry weight (DW) were measured using an electric balance (PG 5002 Delta range, Mettler Toledo, Hampton, USA). The DW was determined after drying in an oven for $24 \mathrm{~h}$ at $50{ }^{\circ} \mathrm{C}$ (Heraeus, D-63450, Hanau, Germany). Leaf area was measured using a leaf area meter (LI-3100, LI-COR, Inc., Lincoln, Nebraska, USA). Specific leaf area (SLA) was calculated according to the following equation: SLA $\left(\mathrm{cm}^{2} \mathrm{~g}^{-1}\right)=$ leaf area/leaf DW.

\subsection{Extraction for Polyphenol Analysis}

Six samples (approximately 5-10 g) from six plants of each treatment were collected and wrapped with aluminum foil. The collected samples were immediately plunged in liquid nitrogen and stored at $-80{ }^{\circ} \mathrm{C}$ until extraction. The protocol described by Ferreres et al. [29] was followed to extract the polyphenol compounds. Five grams of frozen plant material was homogenized with $5 \mathrm{~mL}$ of $\mathrm{MeOH} / \mathrm{AcOH} / \mathrm{H}_{2} \mathrm{O}$ (25:4:21) using Ultra-turrax homogenizer at 13,500 rpm for approximately $1 \mathrm{~min}$. Aliquot and plant particles were separated through a filter paper $(00 \mathrm{H}$, Munktell filter $\mathrm{AB}$, Delsjofors, 
Sweden). Prior to HPLC analysis, an aliquot was filtered through a $0.45 \mu \mathrm{m}$ syringe filter (Q-Max syringe filters, Frisenette Aps, Knebel, Denmark).

\subsection{Estimation of Flavonoid, Anthocyanin, and Chlorogenic Acid by HPLC}

High-performance liquid chromatography (Ultimate 3000, Dionex, Midland, ON, Canada) was used to analyze flavonoid, anthocyanin, and chlorogenic acid content. Chromatographic separation was performed using a Hypersil GOLD RP-18 column $(250 \mathrm{~mm} \times 4.00 \mathrm{~mm}, 5 \mu \mathrm{m})$ equipped with a photodiode array detector (Dionex Ultimate PDA-3000) at a flow rate of $1 \mathrm{~mL} \mathrm{~min}{ }^{-1}$ at $30{ }^{\circ} \mathrm{C}$ with an injection volume of $30 \mu \mathrm{L}$. Eluent A contained $0.05 \%$ trifluoroacetic acid (TFA) in $\mathrm{MeOH}$ and eluent $\mathrm{B}$ contained $0.05 \%$ TFA in $\mathrm{H}_{2} \mathrm{O}$. A linear gradient was used, starting with $5 \% \mathrm{~B}$ in $\mathrm{A}$ to reach $40 \% \mathrm{~B}$ in $\mathrm{A}$ in $25 \mathrm{~min}$. Chromatograms for chlorogenic acid and flavonoid were recorded at $330 \mathrm{~nm}$ and for anthocyanin at $520 \mathrm{~nm}$ wavelength. Chlorogenic acid, flavonoid, and anthocyanin were quantified against chlorogenic acid, quercetin 3-glucoside, and cyanidin 3-glucoside standard, respectively. The results were expressed as $\mu \mathrm{g} \mathrm{g}^{-1} \mathrm{FW}$.

\subsection{Carbohydrate and Pigments Analysis}

Six samples (each sample contained two leaf disks, $7 \mathrm{~mm}$ diameter) from a fully developed leaf (second/third leaf from the top) in each treatment were collected. The leaf disks were placed in a pre-weighed tube (Eppendorf $1.5 \mathrm{~mL}$ ) and then immediately plunged in liquid nitrogen and stored at $-80^{\circ} \mathrm{C}$ until freeze-drying. Before extraction, all frozen samples were freeze-dried, weighed, and ground in a mixer mill (MM200; Retsch, Haan, Germany). Carbohydrates were extracted using the method described by Kjaer et al. [30]. In brief, 3-7 mg of freeze-dried sample was placed in an Eppendorf tube, and $400 \mu \mathrm{L}$ of $80 \%$ ethanol $(96 \%$ ethanol/10 mM HEPES $=80: 20(\mathrm{v} / \mathrm{v})$ ) was added followed by vortexing. The samples were shaken by a hot mixer (Eppendorf Thermomixer Comfort) at $1300 \mathrm{rpm}$ at $80^{\circ} \mathrm{C}$ for $15 \mathrm{~min}$ and then centrifuged at $14,000 \mathrm{rpm}$ for $4 \mathrm{~min}$. The supernatant was collected in a $2 \mathrm{~mL}$ Eppendorf vial and kept on ice in the dark. The remaining pellet was again extracted with $400 \mu \mathrm{lL}$ of $50 \%$ ethanol $\left(96 \%\right.$ ethanol/10 mM HEPES/ $\left./ \mathrm{ddH}_{2} \mathrm{O}=50: 20: 30(\mathrm{v} / \mathrm{v})\right)$ and the supernatant was collected. The pale-colored pellet was kept in a fume hood overnight to allow the evaporation of ethanol. The supernatant was analyzed for pigments and soluble sugars, whereas the pellet was analyzed for glucose residues enzymatically reduced from starch.

Pigments were analyzed using a Spectrophotometer (UV-VIS Spectrophotometer, SHIMADZU) at different wavelengths: 470,648.6, and $664.2 \mathrm{~nm}$. The content of chlorophyll (chl) $a$, chl $b$, total chl and carotenoid were calculated according to Lichtenthaler [31] and expressed as $\mathrm{mg} \mathrm{g}^{-1} \mathrm{DW}$. After pigment analysis, the remaining extract was analyzed for soluble sugars.

The pellet was prepared for starch analysis as described by Kjaer et al. [30]. In brief, $1000 \mu \mathrm{L}$ of distilled water was added to the Eppendorf tube and vortexed. The samples were autoclaved at $120^{\circ} \mathrm{C}$ for $90 \mathrm{~min}$. The samples were then vortexed, and $100 \mu \mathrm{L}$ of the sample was added to $400 \mu \mathrm{L}$ enzyme buffer solution ( $385 \mu \mathrm{L}$ Na-acetate $/ 4 \mu \mathrm{L}$ amyloglucosidase $/ 0.16 \mu \mathrm{L} \alpha$-amylase, $\mathrm{pH} 4.9)$. The samples were shaken with $800 \mathrm{rpm}$ at $37^{\circ} \mathrm{C}$ for $16 \mathrm{~h}$ (Eppendorf Thermomixer Comfort, Hamburg, Germany). After centrifuging at 13,000 rpm for $5 \mathrm{~min}$, the supernatant was collected and filtered through a $0.45 \mu \mathrm{m}$ syringe filter. The starch and soluble sugar concentration were analyzed by ion chromatography using a Dionex ICS-3000 (Dionex, Sunnywale, CA, Sunnyvale, USA) according to Kjaer et al. [30].

\subsection{Statistical Analysis}

Data were analyzed by one-way ANOVA using the R version 3.0.1 (The R Foundation for Statistical Computing, 2019). All data were expressed as mean \pm SD of multiple measurements. The obtained results were compared among the different $\mathrm{B} / \mathrm{R}$ light ratios using a paired $t$-test in order to observe the significant differences at the level of $5 \%$. 


\section{Results and Discussion}

\subsection{Lettuce Plants Adapt Their Photosynthetic Apparatus to the Light Conditions}

As light intensity increases, plants use the absorbed light less efficiently for photosynthesis while the rest of the absorbed light energy is dissipated as heat or chlorophyll fluorescence [32]. Therefore, lower light intensity is expected to be relatively more efficiently used in the photosynthesis process [33]. Lettuce seedlings were grown under $\mathrm{B} / \mathrm{R}$ ratio $=3: 5$ with relatively higher intensity (PPFD) compared to treatment to obtain uniform seedlings as this ratio and PPFD correspond with what is commercially used for the production of leaf lettuce seedlings.

Lettuce plants grown under different $B / R$ light ratios had substantially different leaf net photosynthetic rate $\left(\mathrm{P}_{\mathrm{n}}\right)$, stomatal conductance $\left(\mathrm{g}_{\mathrm{s}}\right)$, and chlorophyll fluorescence $\left(\mathrm{F}_{\mathrm{v}} / \mathrm{F}_{\mathrm{m}}\right)($ Figure 2$)$, especially after 10 DAT. It was observed that a higher fraction of $B$ light $(B / R=5: 1)$ significantly increased $P_{n}$, and that increasing $B / R$ ratios had a continuous increasing effect on $g_{s}$ and $F_{v} / F_{m}$ in young lettuce plants after 10 DAT. This effect disappeared for $P_{n}$ and $F_{v} / F_{m}$ after 20 DAT, whereas increasing B light still seemed to have some effect on $g_{s}$. The results demonstrate that the plants were adapting to the new light conditions after they were placed in the light treatments with both different $\mathrm{B} / \mathrm{R}$ light ratios and lower light intensity, and they were close to being fully adapted after 20 DAT.
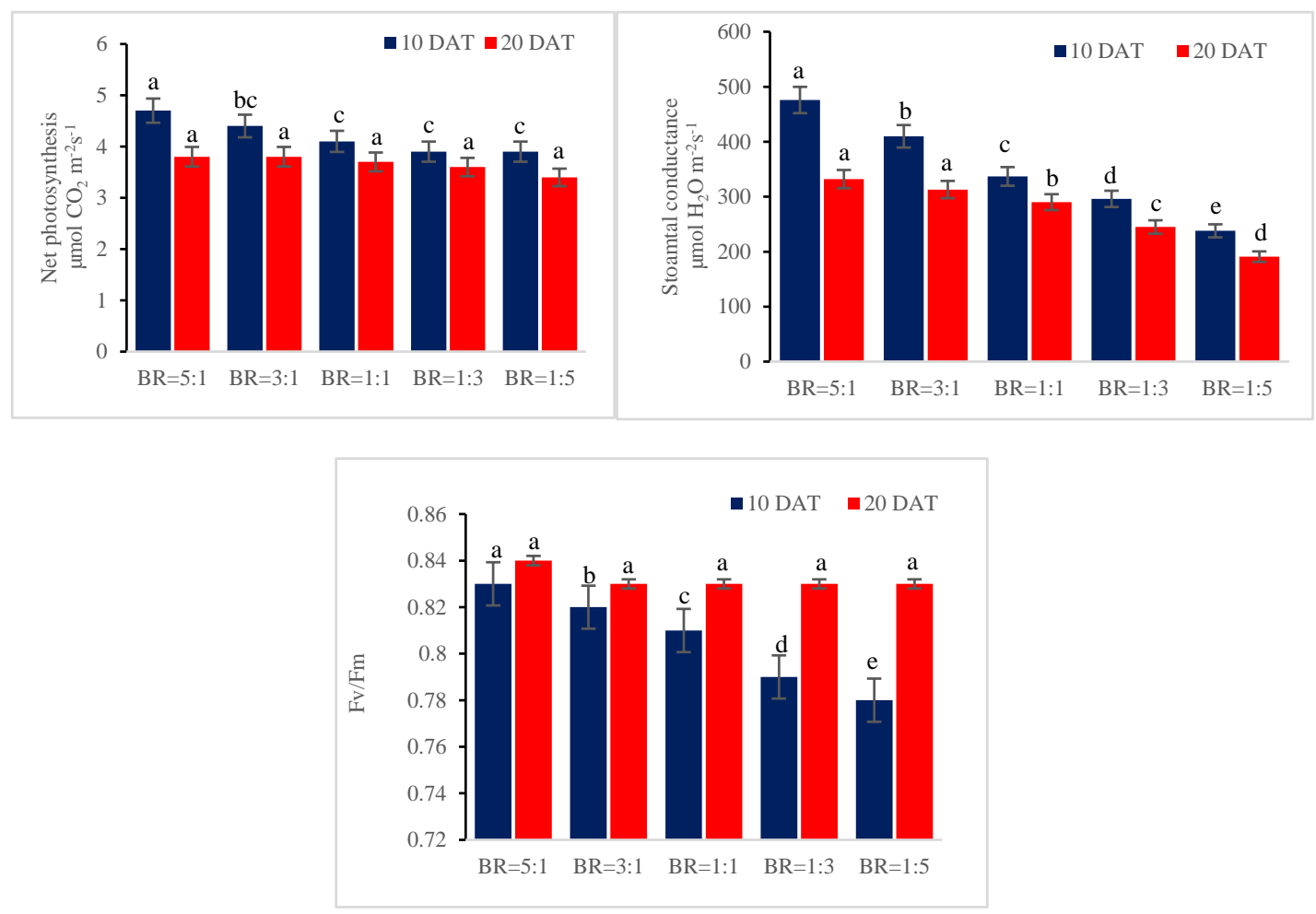

Figure 2. Net photosynthetic rate, stomatal conductance and chlorophyll fluorescence of leaf lettuce grown under different BR light treatments. Values are the means of three separate measurements. Bars indicate SD. Letters indicate mean separation by Duncan's multiple range test $(p<0.05)$. Means with the same letter in each column are not significantly different. DAT = days after the commencement of LED light treatment.

Our results show that when increasing the $\mathrm{B}$ light fraction in $\mathrm{B} / \mathrm{R}$ light combinations, the plants responded by increasing the capacity of their photosynthetic apparatus as reflected by increased $F_{\mathrm{v}} / \mathrm{F}_{\mathrm{m}}$ ratio and chl $a$ content, with a direct effect on $\mathrm{P}_{\mathrm{n}}$. The same trend of increasing $\mathrm{P}_{\mathrm{n}}$ in response to higher B light was also observed in rice plants [34] and in cucumber [9]. B light has earlier been shown to increase the total chl content of lettuce leaves [35]. Wang et al. [36] reported that lettuce 
plants grown under enriched $B$ light led to increased $g_{s}$, resulting in higher $P_{n}$. In our study, $g_{s}$ of 200-400 $\mu \mathrm{mol} \mathrm{m}^{-2} \mathrm{~s}^{-1}$ in the 1:5, 1:3,1:1, and 3:1 treatments was probably not low enough to limit $\mathrm{CO}_{2}$ for photosynthesis compared with the 5:1 treatment, where $\mathrm{g}_{\mathrm{s}}$ was $500 \mu \mathrm{mol} \mathrm{m}{ }^{-2} \mathrm{~s}^{-1}$ after 10 DAT.

It is known that stomatal regulation is a B light-mediated response regulated by phototropin receptors [37] and controlled by a negative electrical gradient potential in the plasma membrane, which increases the potassium content in the guard cell and drives stomatal opening [38]. The B light response of improved stomatal regulation was confirmed by Shimazaki [39], who noted that a higher $\mathrm{B} / \mathrm{R}$ ratio improved the stomatal regulation by activating a signaling cascade of phototropins.

In our study, the $\mathrm{F}_{\mathrm{v}} / \mathrm{F}_{\mathrm{m}}$ ratio was significantly increased by higher $\mathrm{B} / \mathrm{R}$ light for the young lettuce plants after 10 DAT. Similar results were also shown by Son et al. [15], who demonstrated that the $\mathrm{F}_{\mathrm{v}} / \mathrm{F}_{\mathrm{m}}$ ratio decreased when the fraction of $\mathrm{R}$ light increased in leaf lettuce. However, higher $\mathrm{F}_{\mathrm{v}} / \mathrm{F}_{\mathrm{m}}$ ratios are also seen as a response to low light intensities, which is part of a common shade adaptation strategy [40]. It was noted that the $\mathrm{F}_{\mathrm{v}} / \mathrm{F}_{\mathrm{m}}$ ratio is aligned with the photochemical efficiency of PSII, and that low $F_{v} / F_{m}$ values may indicate plant stress [28]. The high values of $F_{v} / F_{m}$ in the present study displayed that the plants were not stressed. Overall, the results demonstrate that the lettuce plants had increased maximum photochemical efficiency of PSII and had acclimated to the different light conditions after being exposed to the different $\mathrm{B} / \mathrm{R}$ ratios for approximately $20 \mathrm{DAT}$.

\subsection{Lettuce Morphology Characteristics Are Affected by the B/R Light Ratio}

The different $\mathrm{B} / \mathrm{R}$ light ratios had significant effects on the growth and morphology characteristics of lettuce at both harvesting stages (Tables 1 and 2). From our study, it was observed that an overall increasing fraction of $\mathrm{R}$ light ( $\mathrm{B} / \mathrm{R}=1: 5)$ increased plant height, leaf area (LA), specific leaf area (SLA), fresh weight (FW), and dry weight (DW) at both harvesting days (10 and 20 DAT).

Table 1. Growth characteristics of lettuce grown under different ratios of B/R light treatments at 10 DAT.

\begin{tabular}{|c|c|c|c|c|c|c|}
\hline Treatments & $\begin{array}{l}\text { Plant Height } \\
\text { (cm) }\end{array}$ & $\begin{array}{l}\text { Leaf Number } \\
\text { Plant }^{-1}\end{array}$ & $\begin{array}{l}\text { LA Plant } \\
\left(\mathrm{cm}^{2}\right)\end{array}$ & $\begin{array}{l}\text { SLA Plant }^{-1} \\
\left(\mathrm{~cm}^{2} \mathrm{~g}^{-1}\right)\end{array}$ & $\begin{array}{l}\text { FW Plant } \\
\text { (g) }\end{array}$ & $\begin{array}{c}\text { DW } \text { Plant }^{-1} \\
\text { (g) }\end{array}$ \\
\hline $\mathrm{B} / \mathrm{R}=5: 1$ & $7.10 \pm 0.96 d^{y}$ & $6 \pm 0.69 a$ & $87 \pm 25.5 \mathrm{~d}$ & $473 \pm 102 b$ & $3.0 \pm 1.00 \mathrm{~b}$ & $0.18 \pm 0.06 \mathrm{ab}$ \\
\hline $\mathrm{B} / \mathrm{R}=3: 1$ & $8.3 \pm 0.94 c$ & $6 \pm 0.48 a$ & $119 \pm 21.4 b c$ & $469 \pm 85 b$ & $4.0 \pm 0.89 \mathrm{a}$ & $0.26 \pm 0.07 \mathrm{a}$ \\
\hline $\mathrm{B} / \mathrm{R}=1: 1$ & $9.7 \pm 0.63 b$ & $6 \pm 0.42 a$ & $111 \pm 12.6 c$ & $602 \pm 108 a$ & $4.2 \pm 0.70 \mathrm{~b}$ & $0.19 \pm 0.05 \mathrm{ab}$ \\
\hline $\mathrm{B} / \mathrm{R}=1: 3$ & $10.0 \pm 0.55 b$ & $6 \pm 0.56 a$ & $137 \pm 14.2 \mathrm{ab}$ & $546 \pm 69 \mathrm{ab}$ & $5.0 \pm 0.74 \mathrm{a}$ & $0.25 \pm 0.04 a$ \\
\hline $\mathrm{B} / \mathrm{R}=1: 5$ & $11.0 \pm 0.62 \mathrm{a}$ & $6 \pm 0.31 a$ & $149 \pm 15.9 \mathrm{a}$ & $632 \pm 75 a$ & $4.6 \pm 0.74 \mathrm{a}$ & $0.24 \pm 0.03 a$ \\
\hline
\end{tabular}

Table 2. Growth parameters and biomass of lettuce grown under different ratios of B/R light treatments at 20 DAT.

\begin{tabular}{|c|c|c|c|c|c|c|}
\hline Treatments & $\begin{array}{c}\text { Plant } \\
\text { Height }(\mathrm{cm})\end{array}$ & $\begin{array}{c}\text { Leaf Number } \\
\text { Plant }^{-1}\end{array}$ & $\begin{array}{l}\text { LA Plant } \\
\qquad\left(\mathrm{cm}^{2}\right)\end{array}$ & $\begin{array}{l}\text { SLA Plant } \\
\left(\mathrm{cm}^{2} \mathrm{~g}^{-1}\right)\end{array}$ & $\begin{array}{c}\text { FW } \text { Plant }^{-1} \\
(\mathrm{~g})\end{array}$ & $\begin{array}{c}\text { DW } \text { Plant }^{-1} \\
(\mathrm{~g})\end{array}$ \\
\hline$B / R=5: 1$ & $9.7 \pm 0.58 \mathrm{~d}^{\mathrm{y}}$ & $10 \pm 1.0 \mathrm{a}$ & $234 \pm 35.1 c$ & $539 \pm 58 b$ & $9.4 \pm 1.6 a$ & $0.44 \pm 0.08 \mathrm{a}$ \\
\hline $\mathrm{B} / \mathrm{R}=3: 1$ & $10.1 \pm 0.41 \mathrm{~d}$ & $10 \pm 0.66 a$ & $255 \pm 34.0 \mathrm{bc}$ & $580 \pm 181 b$ & $10.6 \pm 1.4 a$ & $0.46 \pm 0.10 a$ \\
\hline $\mathrm{B} / \mathrm{R}=1: 1$ & $11.0 \pm 0.82 c$ & $9 \pm 0.82 \mathrm{ab}$ & $243 \pm 20.4 b c$ & $485 \pm 218 b$ & $10.3 \pm 1.1 \mathrm{a}$ & $0.55 \pm 0.15 a$ \\
\hline $\mathrm{B} / \mathrm{R}=1: 3$ & $11.9 \pm 0.56 b$ & $10 \pm 0.69 \mathrm{ab}$ & $271 \pm 21.9 \mathrm{ab}$ & $1044 \pm 175 a$ & $10.7 \pm 0.8 a$ & $0.26 \pm 0.04 b$ \\
\hline $\mathrm{B} / \mathrm{R}=1: 5$ & $12.7 \pm 0.92 \mathrm{a}$ & $9 \pm 0.63 \mathrm{ab}$ & $295 \pm 32.9 a$ & $1275 \pm 399 a$ & $10.9 \pm 1.6 a$ & $0.25 \pm 0.09 b$ \\
\hline
\end{tabular}

y Mean separation within columns by DMRT test at $5 \%$ significant level. The values are means \pm SE of ten separate measurements. Means with the same letter in a column are not significantly different.

Lettuce plants have earlier been shown to have a higher growth rate, i.e., plant height, LA, SLA, FW, and DW, when they were exposed to a high portion of R light [15]. The constructive effect of $R$ light on the growth of various herbs has previously been studied [17,41]. It is understood that $\mathrm{R}$ light stimulates phytochrome photoreceptors (PPs) through activation of the HY5 gene, which regulates plant growth [42,43]. Martinez-Garcia et al. [44] also exemplified that R light activates PPs, which induces relocalization to the nucleus and modulates gene expression. In the present study, plant 
height, LA, and SLA were significantly increased by a higher R light fraction in BR light ratios. These results support earlier evidence that increasing the ratio of $R$ to $B$ light increases the hypocotyl length in lettuce [45]. The lower leaf LA and plant height in treatments with high B/R light ratios may be associated with a B light-mediated inhibition of cell expansion [46]. A similar result was reported by Samuoliene et al. [47], who showed that an optimal combination of B/R light ratios enhances the plant growth rate in controlled conditions. However, the optimal $\mathrm{B} / \mathrm{R}$ ratio differed according to plant species, growth periods, and the targeted qualities [48].

Lettuce plants had a compact leaf arrangement with dark green color and small petioles when grown under a higher $B$ light fraction $(B / R=5: 1)$, whereas plants grown under a lower $B$ light fraction had a pale green color and leaves that were more spread out and with long petioles (Figure 3). Kang et al. [49] also reported that lettuce plants had compact leaves and short petioles under higher $\mathrm{B} / \mathrm{R}$ light ratios.

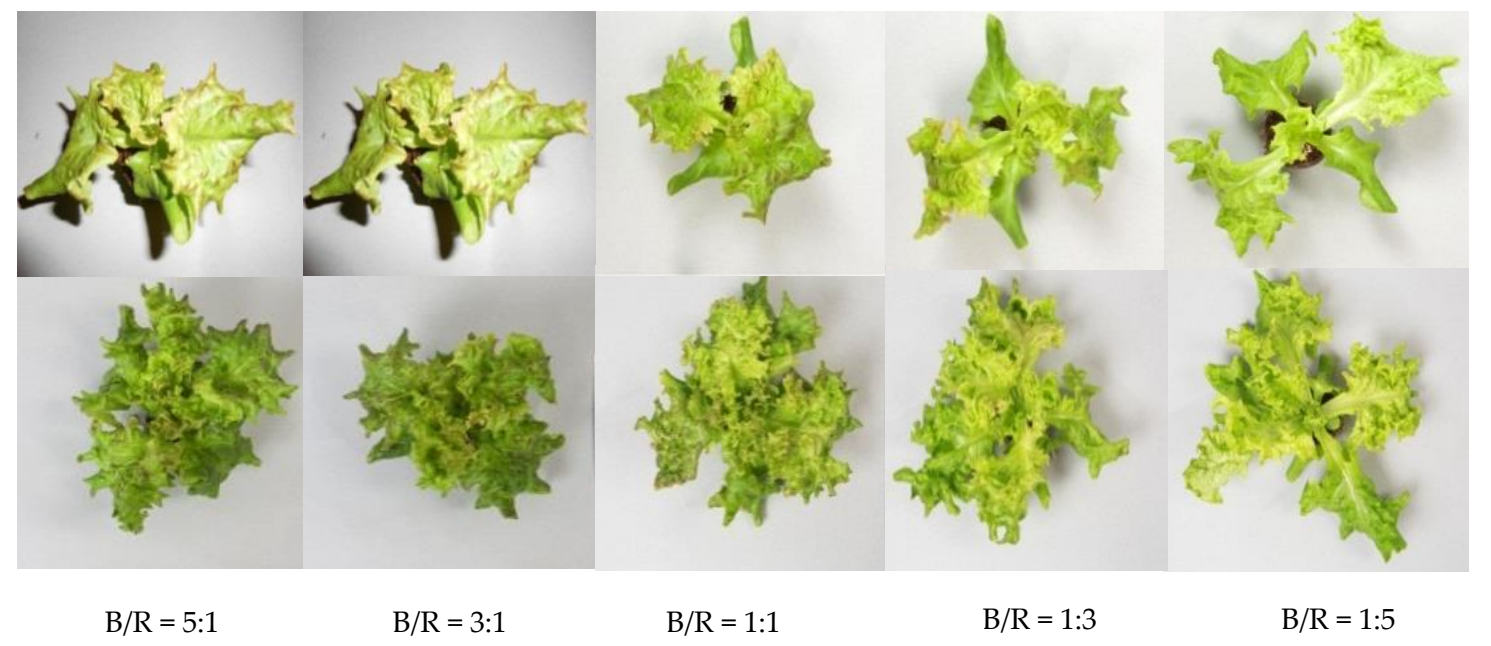

Figure 3. Lettuce plant shape and size at 10 (first row) and 20 DAT (second row) under different BR light ratios.

Johkan et al. [35] showed that compact growth and reduced height of lettuce is typical when a plant is exposed to B light. Chatterjee et al. [50] reported that B light was intercepted via cryptochrome photoreceptors (CRY1) to upregulate gene expression within the gibberellic acid biosynthetic pathway. As a result, B light caused short stems and compact growth. Similar effects of B and R light on lettuce morphology were observed by Metallo et al. [51]. They found kale to be short and compact when grown under higher $B / R$ light ratios. Previous researchers described that varying the fraction of $R$ and B light is a useful tool to obtain the desired morphological shape of targeted plants $[52,53]$.

\subsection{Red Light Increase Carbohydrate Contents}

Glucose, fructose, sucrose, and starch contents in lettuce were significantly increased under lower B/R light ratios (1:1, 1:3, 1:5) at both growing stages (Figure 4A-D). Carbohydrates are the final product of photosynthesis and an important parameter to assess the nutritional quality of lettuce [54]. Generally, high soluble sugars such as glucose, fructose, and sucrose content in lettuce resulted in a more pleasant taste [54]. According to our data, glucose, fructose, and sucrose increased with an increasing portion of $\mathrm{R}$ light. Previously, it was reported that $\mathrm{R}$ light is the most effective light source for accumulating starch in many plant species, including Chinese cabbage, soybean, and sorghum [55]. $\mathrm{R}$ light prevents the translocation of photosynthates and, thus, enhances starch accumulation [56]. The present results also demonstrate that a high portion of $\mathrm{R}$ light promoted the starch content in lettuce, whereas the starch content was lower in high B light treatments, consistent with a previous study [57]. Poffenroth et al. [58] demonstrated that B light degrades starch to sucrose but, on the other 
hand, sucrose was converted to starch by red light in the presence of $\mathrm{KCl}$. Yagi et al. [59] also described that $\mathrm{R}$ light stimulated starch accumulation by increasing the abundance of a number of enzymes related to carbon fixation in the Calvin cycle. Li et al. [55] found higher soluble sugar concentrations under R light compared to B light in pea sprouts and Chinese cabbage.
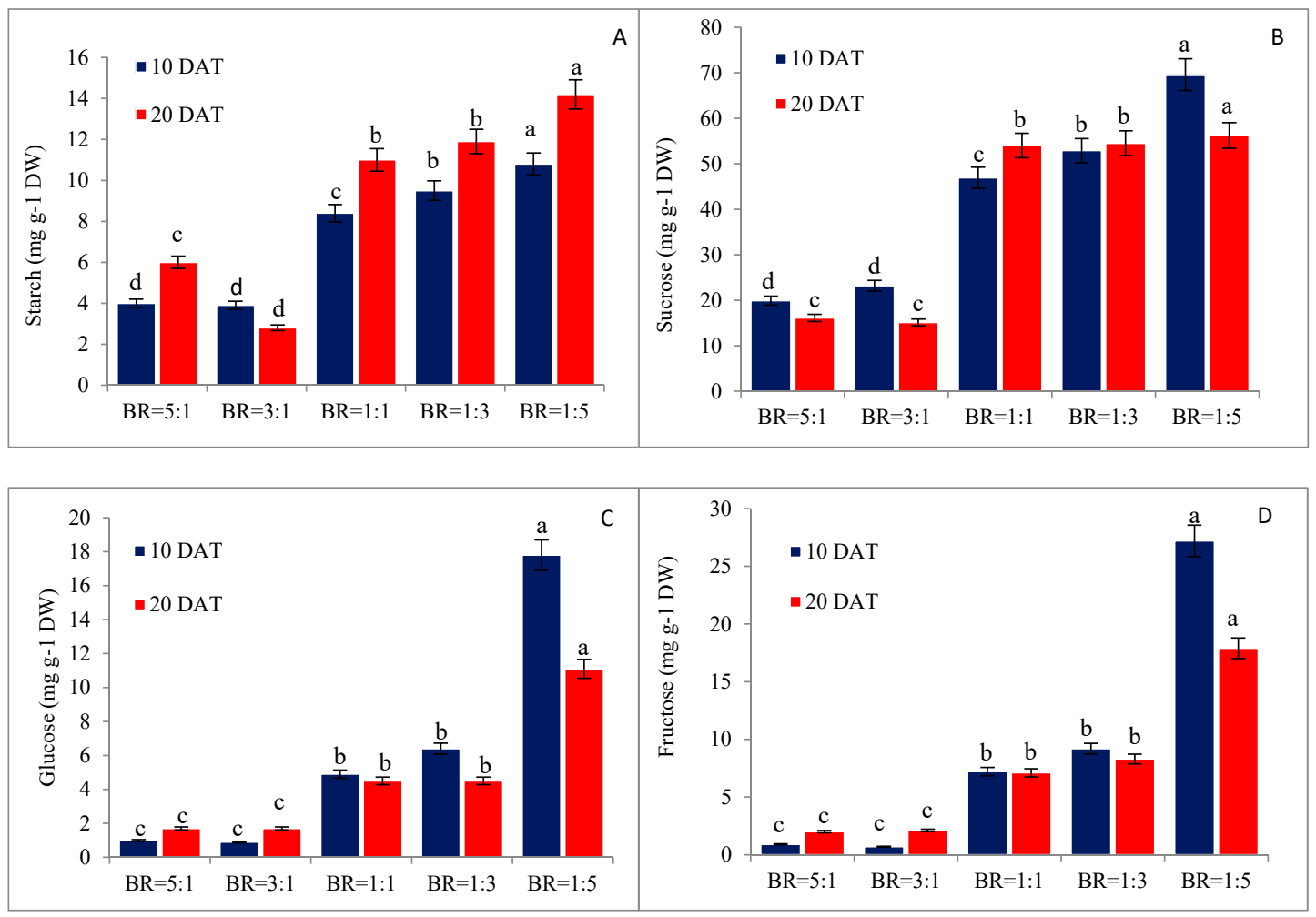

Figure 4. Starch (A), sucrose (B), glucose (C), and fructose (D) contents in leaf lettuce grown under different ratios of BR light ratios. Bars indicate SD of eight separate measurements. Values are the means of three separate measurements. Bars indicate SD. Letters indicate mean separation by Duncan's multiple range test $(p<0.05)$. Means with the same letter in each column are not significantly different. DAT $=$ days after the onset of light treatments.

In the current study, the starch concentration was higher at 20 DAT, whilst the concentration of soluble sugars had a declining trend at 20 DAT (Figure 4). Cheng et al. [60] noticed that plant source-sink relationships influence the carbohydrate allocation during plant growth. Sucrose is the primary carbohydrate that is translocated from source to sink tissues. Lettuce plants might have low sink demand owing to low developmental progress at later growth stages. This hypothesis is supported by Cheng et al. [60], who found lower carbohydrate contents at later growth stages in peach.

\subsection{Blue Light Increases the Leaf Content of Pigments}

In our study, the chlorophyll (chl) $a, \mathrm{chl} b, \mathrm{chl} a / b$ ratio, total chl, and carotenoids were significantly increased in lettuce grown under higher $\mathrm{B} / \mathrm{R}$ ratios at both harvesting times (Table 3 ). It is well established that plant pigments receive a very specific light spectrum through their light harvesting antenna, i.e., chlorophyll and carotenoid pigment absorb at wavelengths $400-500 \mathrm{~nm}$ and $630-680 \mathrm{~nm}$ of the light spectrum $[44,54]$. 
Table 3. Pigments content of lettuce grown under different ratios of $\mathrm{B} / \mathrm{R}$ light treatments.

\begin{tabular}{|c|c|c|c|c|c|c|c|c|c|c|}
\hline \multirow{2}{*}{ Treatments } & \multicolumn{2}{|c|}{ Chl $a \mathrm{mg} \mathrm{g}^{-1} \mathrm{DW}$} & \multicolumn{2}{|c|}{ Chl $b \mathrm{mg} \mathrm{g}^{-1} \mathrm{DW}$} & \multicolumn{2}{|c|}{ Total Chl $\mathrm{mg} \mathrm{g}^{-1} \mathrm{DW}$} & \multicolumn{2}{|c|}{ Chl $a / b$ Ratio } & \multicolumn{2}{|c|}{ Carotenoid $\mathrm{mg} \mathrm{g}^{-1} \mathrm{DW}$} \\
\hline & 10 DAT & 20 DAT & 10 DAT & 20 DAT & 10 DAT & 20 DAT & 10 DAT & 20 DAT & 10 DAT & 20 DAT \\
\hline $\mathrm{B} / \mathrm{R}=5: 1$ & $9.2 \pm 2.0 \mathrm{a}^{\mathrm{y}}$ & $9.6 \pm 2.5 a$ & $2.9 \pm 0.7 a$ & $4.1 \pm 0.5 a$ & $12.0 \pm 2.7 \mathrm{a}$ & $13.7 \pm 2.9 \mathrm{a}$ & $3.2 \pm 0.2 a$ & $2.3 \pm 0.5 b$ & $3.1 \pm 0.4 a$ & $3.8 \pm 0.8 \mathrm{a}$ \\
\hline $\mathrm{B} / \mathrm{R}=3: 1$ & $6.3 \pm 1.3 b$ & $6.2 \pm 2.1 b$ & $2.4 \pm 0.5 a$ & $2.4 \pm 0.9 b$ & $8.7 \pm 1.4 b$ & $8.6 \pm 3.0 \mathrm{~b}$ & $2.8 \pm 0.9 a$ & $2.6 \pm 0.3 \mathrm{ab}$ & $2.5 \pm 0.6 b$ & $2.0 \pm 0.7 \mathrm{~b}$ \\
\hline $\mathrm{B} / \mathrm{R}=1: 1$ & $4.7 \pm 0.7 b c$ & $5.8 \pm 1.5 b$ & $2.4 \pm 0.5 a$ & $2.1 \pm 0.8 b$ & $7.2 \pm 1.1 b$ & $7.9 \pm 2.2 b$ & $1.9 \pm 0.2 b$ & $2.8 \pm 0.6 \mathrm{ab}$ & $1.8 \pm 0.3 c$ & $2.0 \pm 0.7 \mathrm{~b}$ \\
\hline $\mathrm{B} / \mathrm{R}=1: 3$ & $4.6 \pm 0.9 c$ & $6.0 \pm 0.9 b$ & $2.5 \pm 0.5 a$ & $2.0 \pm 0.5 b$ & $7.1 \pm 1.3 b$ & $8.1 \pm 1.4 b$ & $1.8 \pm 0.2 b$ & $3.0 \pm 0.4 a$ & $1.9 \pm 0.4 \mathrm{c}$ & $1.5 \pm 0.2 b$ \\
\hline $\mathrm{B} / \mathrm{R}=1: 5$ & $4.5 \pm 0.4 \mathrm{c}$ & $4.8 \pm 1.5 b$ & $2.3 \pm 0.4 a$ & $1.8 \pm 0.9 b$ & $6.8 \pm 0.7 \mathrm{~b}$ & $6.6 \pm 2.4 b$ & $1.9 \pm 0 . b$ & $2.8 \pm 0.6 \mathrm{ab}$ & $1.7 \pm 0.2 \mathrm{c}$ & $1.6 \pm 0.9 b$ \\
\hline
\end{tabular}

y Mean separation within columns by DMRT test at $5 \%$ significant level. The values are means \pm SE of eight separate measurements. Means with the same letter in column are not significantly different. DAT = days after the onset of light treatments. 
$\mathrm{B}$ light is profusely absorbed by the photosynthetic antenna of plant pigment, which works as a catalytic agent to accumulate the pigment including chl and carotenoid content in plant leaves $[9,57]$.

In our current study, it is demonstrated that higher B/R light enhanced the chl and carotenoid content in leaf lettuce. This finding is consistent with the previous reports of $\mathrm{Li}$ et al. [55] and Son et al. [15]. The enhanced chl and carotenoid content of lettuce under B light treatment are due to the stimulation, induction, and synthesis of the principal gene (PAL gene activity) in chl and carotenoid by B light [61,62]. Earlier Johkan et al. [35] stated that chl molecules and $p_{n}$ have a linear relationship in which a higher chl could increase the rate of $\mathrm{p}_{\mathrm{n}}$. In the current study, it is shown that higher chl molecules increased the rate of $\mathrm{p}_{\mathrm{n}}$ (Table 3 and Figure 2). Plants were grown under higher $\mathrm{B} / \mathrm{R}$ light ratios had a higher $\mathrm{chl} a / b$ ratio. A higher $\mathrm{chl} a / b$ indicates a high-light-adapted photosynthetic apparatus and a higher capacity for electron transport in the Calvin cycle [63]. Enhanced chl content under higher $B$ light treatment is associated with $\mathrm{p}_{\mathrm{n}}$ activities. Yu et al. [64] stated that the enhancement of carotenoid under higher $\mathrm{B} / \mathrm{R}$ ratio is due to the stimulation of cryptochrome activity.

\subsection{Blue Light Increases the Content of Phenolic Compounds}

Anthocyanin, flavonoids, and chlorogenic acids significantly increased when B light was favored in the balance between B and R (Figures 5 and 6). High B/R light ratios have also earlier been shown to be vital for the accumulation of bioactive compounds such as anthocyanin, chlorogenic acid, and flavonoids in lettuce $[15,35]$. Furthermore, in our study, all phenolic compounds were higher after 10 DAT than 20 DAT (Figures 5-7). It has earlier been reported that the accumulation of bioactive compounds depends on the plant growth stage [65]. In previous reports, the levels of anthocyanin, chlorogenic acid, and flavonoid were found to be higher in developing leaves than the comparatively matured leaves in leaf lettuce [35].

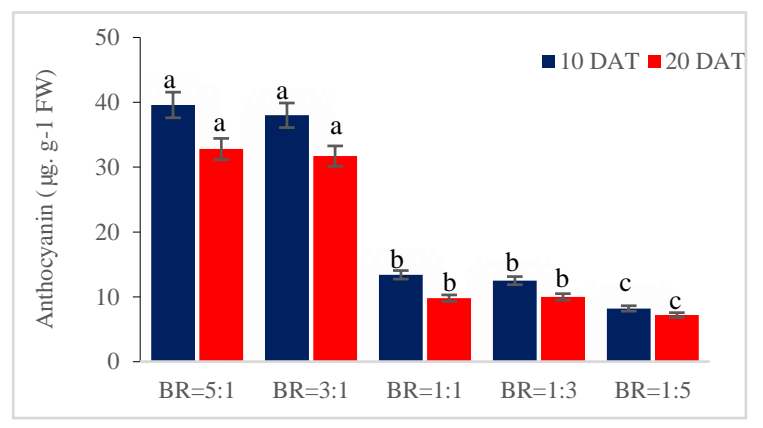

Figure 5. Anthocyanin content of lettuce grown under different ratios of BR light treatments. Bars indicate SD of six separate measurements. Letters indicate mean separation by Duncan's multiple range test $(p<0.05)$. Means with the same letter in each column are not significantly different. DAT $=$ days after the onset of light treatments.

Bian et al. [66] noted that a higher B/R light fraction led to increased anthocyanin content in leaf lettuce. The previous report revealed that $B$ light is the most operative light spectrum for the synthesis of anthocyanin and flavonoid compounds by stimulating PAL (phenylalanine ammonia-lyase), CHS (chalcone synthesis), and DFR (dihydroflavonol-4-reductase) gene expression [67]. B light has also been shown to be the most effective light for promoting chlorogenic acid synthesis [68]. Giliberto et al. [69] reported that B light photoreceptors, such as cryptochromes, are involved in chlorogenic acid synthesis. The study showed that B light stimulated PAL (phenylalanine) activity in phenylpropanoid pathways, which promotes chlorogenic acid accumulation [70]. 


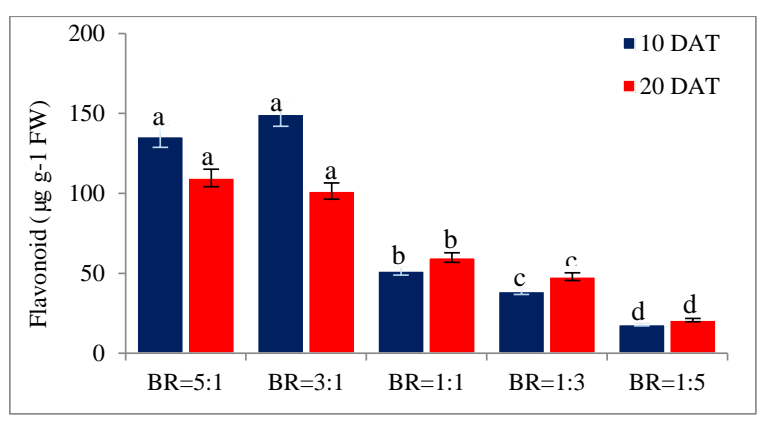

Figure 6. Flavonoid content of lettuce grown under different ratios of BR light treatments. Bars indicate SD of six separate measurements. Letters indicate mean separation by Duncan's multiple range test $(p<0.05)$. Means with the same letter in each column are not significantly different. DAT $=$ days after the onset of light treatments.

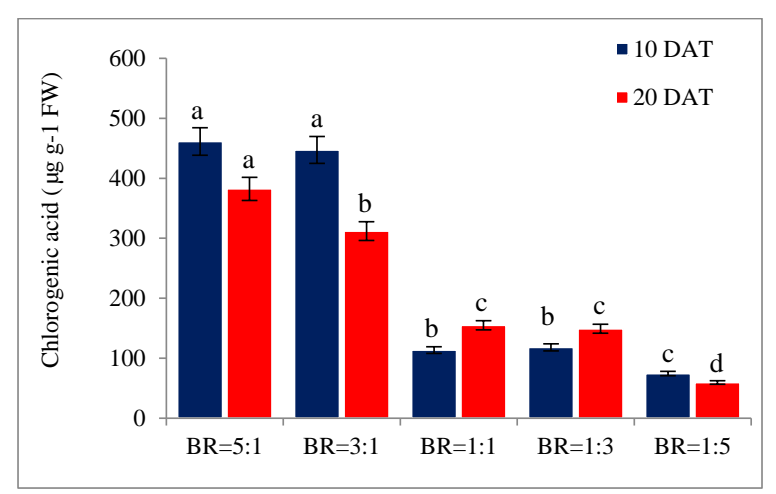

Figure 7. The chlorogenic acid content of lettuce grown under different ratios of BR light treatments. Bars indicate SD of six separate measurements. Values are the means of three separate measurements. Bars indicate SD. Letters indicate mean separation by Duncan's multiple range test $(p<0.05)$. Means with the same in each column letter are not significantly different. DAT $=$ days after the onset of light treatments.

\section{Conclusions}

In this study, we have demonstrated that lettuce plant exhibits normal growth and metabolic activity when grown under comparatively limited BR light irradiation. Overall, the results show that the lettuce plants appeared more compact when grown under higher B light fraction, with smaller leaves at an early stage. It was also observed that higher B light fraction increased the content of pigments and phenolic compounds while higher $\mathrm{R}$ light fraction increased the carbohydrate contents. This knowledge can be used to select the most appropriate $\mathrm{B} / \mathrm{R}$ light ratio for lettuce production under low light regimes in urban plant factories and under extreme conditions, such as in arctic regions or even in space farming.

Author Contributions: M.O.K.A. performed the experiment, analyzed the data, and drafted the manuscript, K.H.K. assisted performing the experiment, and the analysis of the data, and critically reviewed the manuscript, M.A., M.T.N., C.H.P., I.J.S., J.D.L. and Y.S.L. revised and improved the manuscript. All authors have read and agreed to the published version of the manuscript.

Funding: This research was funded by the Aarhus University, Denmark.

Acknowledgments: We highly acknowledge the Department of Food Science, Aarhus University, Denmark, for their kind cooperation in performing this experiment.

Conflicts of Interest: The authors declare no conflict of interest. 


\section{References}

1. Kozai, T. Smart Plant Factory-The Next Generation Indoor Vertical Farms; Springer: Berlin, Germany, 2018.

2. Mou, B. Nutritional quality of lettuce. Curr. Nutr. Food Sci. 2012, 8, 177-187. [CrossRef]

3. Konstantopoulou, E.; Kapotis, G.; Salachas, G.; Petropoulos, S.A.; Karapanos, I.C.; Passam, H.C. Nutritional quality of greenhouse lettuce at harvest and after storage in relation to $\mathrm{N}$ application and cultivation season. Sci. Hortic. 2010, 125, 93-94. [CrossRef]

4. Park, Y.G.; Park, J.E.; Hwang, S.J.; Jeong, B.R. Light source and $\mathrm{CO}_{2}$ concentration affect growth and anthocyanin content of lettuce under controlled environment. Hortic. Environ. Biotechnol. 2012, 53, 460-466. [CrossRef]

5. Naznin, M.T.; Lefsrud, M.; Gravel, V.; Azad, M.O.K. Blue light added with red LEDs enhance growth characteristics, pigments content, and antioxidant capacity in lettuce, spinach, kale, basil, and sweet pepper in a controlled environment. Plants 2019, 8, 93. [CrossRef] [PubMed]

6. Naznin, M.T.; Lefsrud, M.; Azad, M.O.K.; Park, C.H. Effect of different combinations of red and blue LED light on growth characteristics and pigment content of in vitro tomato plantlets. Agriculture 2019, 9, 196. [CrossRef]

7. Chen, X.L.; Yang, Q.C.; Song, W.P.; Wang, L.C.; Go, W.Z. Growth and nutritional properties of lettuce affected by different alternating intervals of red and blue LED irradiation. Sci. Hortic. 2017, 223, 4-52. [CrossRef]

8. Terashima, I.; Fujita, T.; Inoue, T.; Chow, W.S.; Oguchi, R. Green light drives leaf photosynthesis more efficiently than red light in strong white light: Revisiting the enigmatic question of why leaves are green. J. Plant Cell Physiol. 2009, 50, 684-697. [CrossRef]

9. Hogewoning, S.W.; Trouwborst, G.; Maljiaars, H.; Poorter, H.; Van leperen, W.; Harbinson, J. Blue light dose-responses of leaf photosynthesis, morphology, and chemical composition of cucumis sativus grown under different combinations of red and blue light. J. Exp. Bot. 2010, 61,3107-3117. [CrossRef]

10. Abidi, F.; Girault, T.; Douillet, O.; Guillemain, G.; Sintes, G.; Laffaire, M.; Leduc, N. Blue light effects on rose photosynthesis and photomorphogenesis. Plant Biol. 2013, 15, 67-74. [CrossRef]

11. Ouzounis, T.; Rosenqvist, E.; Ottosen, C.O. Spectral effects of artificial light on plant physiology and secondary metabolism: A review. Hortscience 2015, 50, 1128-1135. [CrossRef]

12. Perez-Balibrea, S.; Moreno, D.A.; Garcia- Viguera, C. Influence of light on health-promoting phytochemicals of broccoli sprouts. J. Sci. Food Agric. 2008, 88, 904-910. [CrossRef]

13. Kim, S.J.; Hahn, E.J.; Heo, J.W.; Paek, K.Y. Effects of LEDs on net photosynthetic rate, growth and leaf stomata of chrysanthemum plantlets in vitro. Sci. Hortic. 2004, 101, 143-151. [CrossRef]

14. Wu, M.C.; Hou, C.Y.; Jiang, C.M.; Wang, C.Y.; Chen, H.H.; Chang, H.M. A novel approach of LED light radiation improves the antioxidant activity of pea seedlings. Food Chem. 2007, 101, 1753-1758. [CrossRef]

15. Son, K.H.; Oh, M.M. Leaf shape, growth and antioxidant, phenolic compounds of two lettuce cultivars grown under various combinations of blue and red light-emitting diodes. HortScience 2013, 48, 988-995. [CrossRef]

16. Shin, K.S.; Mrthy, H.N.; Heo, J.W.; Hahn, E.J.; Paek, K.Y. The effect of light quality on the growth and development of in vitro cultured doritaenopsis plants. Acta Physiol. Plant. 2008, 30, 339-343. [CrossRef]

17. Lee, J.G.; Oh, S.S.; Cha, S.H.; Jang, Y.A.; Kim, S.Y.; Um, Y.C.; Cheong, S.R. Effects of red/blue light ratio and short-term light quality conversion on growth and anthocyanin contents of baby leaf lettuce. Prot. Hortic. Plant Fact. 2010, 19, 351-359.

18. Becker, C.; Klaering, H.P.; Schreiner, M.; Kroh, L.W.; Krumbein, A. Unlike quercetin glycosides, cyanidin glycoside in red leaf lettuce responds more sensitively to increasing low radiation intensity before than after head formation has started. J. Agric. Food Chem. 2014, 62, 6911-6917. [CrossRef]

19. Urrestarazu, M.; Najera, C.; del Mar Gea, M. Effect of the spectral quality and intensity of light-emitting diodes on several horticultural crops. HortScience 2016, 51, 268-271. [CrossRef]

20. Zhen, S.; van Iersel, M.W. Photochemical acclimation of three contrasting species to different light levels: Implications for optimizing supplemental lighting. J. Am. Soc. Hort. Sci. 2017, 142, 346-354. [CrossRef]

21. Rouphael, Y.; Petropoulos, S.A.; El-Nakhel, C.; Pannico, A.; Kyriacou, M.C.; Giordano, M.; Troise, A.D.; Vitaglione, P.; De Pascale, S. Reducing energy requirements in future bioregenerative life support systems (blsss): Performance and bioactive composition of diverse lettuce genotypes grown under optimal and suboptimal light conditions. Front. Plant Sci. 2019, 10, 1305. [CrossRef] 
22. Huang, L.C.; Chen, Y.H.; Chen, Y.H.; Wang, C.F.; Hu, M.C. Food-energy interactive tradeoff analysis of sustainable urban plant factory production systems. Sustainability 2018, 10, 446. [CrossRef]

23. Kikuchi, Y.; Kanematsu, Y.; Yoshikawa, N.; Okubo, T.; Takagaki, M. Environmental and resource use analysis of plant factories with energy technology options: A case study in Japan. J. Clean. Prod. 2018, 186, 703-717. [CrossRef]

24. Yeh, N.; Chung, J.P. High-brightness LEDs-Energy efficient lighting sources and their potential in indoor plant cultivation. Renew. Sustain. Energy 2009, 13, 2175-2180. [CrossRef]

25. Perez, V.M. Study of the Sustainability Issues of Food Production Using Vertical Farm Methods in an Urban Environment Within the State of Indiana. Master's Thesis, Purdue University, West Lafayette, IN, USA, 2014.

26. Loconsole, D.; Cocetta, G.; Santoro, P.; Ferrante, A. Optimization of led lighting and quality evaluation of romaine lettuce grown in an innovative indoor cultivation system. Sustainability 2019, 11, 841. [CrossRef]

27. Han, T.; Vaganov, V.; Cao, S.; Li, Q.; Ling, L.; Cheng, X.; Peng, L.; Zhang, C.; Yakovlev, A.N.; Zhong, Y.; et al. Improving "color rendering" of LED lighting for the growth of lettuce. Sci. Rep. 2017, 7, 45944. [CrossRef]

28. Maxwell, K.; Johnson, G.N. Chlorophyll fluorescence-A practical guide. J. Exp. Bot. 2000, 51, 659-668. [CrossRef]

29. Ferreres, F.; Gil, M.I.; Castaner, M.; Tomas-Barberan, F.A. Phenolic metabolites in red pigmented lettuce (Lactuca sativa L.) changes with minimal processing and cold Storage. J. Agric. Food Chem. 1997, 45, 4249-4254. [CrossRef]

30. Kjaer, K.H.; Ottosen, C.O. Growth of chrysanthemum in response to supplemental light provided by irregular light breaks during the night. J. Am. Soc. Hort. Sci. 2011, 136, 3-9. [CrossRef]

31. Lichtenthaler, H.K. Chlorophylls and carotenoids: Pigments of photosynthetic biomembranes. Methods Enzymol. 1987, 148, 350-382.

32. Van Iersel, M.W.; Weaver, G.; Martin, M.T.; Ferrarezi, R.S.; Mattos, E.; Haidekker, M. A chlorophyll fluorescence-based biofeedback system to control photosynthetic lighting in controlled environment agriculture. J. Am. Soc. Hort. Sci. 2016, 141, 169-176. [CrossRef]

33. Van Iersel, M.W.; Gianino, D. An adaptive control approach for LED lights can reduce the energy costs of supplemental lighting in greenhouses. HortScience 2017, 52, 72-77. [CrossRef]

34. Matsuda, R.; Ohashi-kaneko, K.; Fujiwara, K.; Goto, E.; Kurata, K. Photosyntehtic characteristics of rice leaves grown under red light with or without supplemental blue light. Plant Cell Physiol. 2004, 45, 1870-1874. [CrossRef] [PubMed]

35. Johkan, M.; Shoji, K.; Goto, F.; Hahida, S.; Yoshihara, T. Blue light emitting diode light irradiation of seedlings improves seedling quality and growth after transplanting in red leaf lettuce. HortScience 2010, 45, 1809-1814. [CrossRef]

36. Wang, J.; Lu, W.; Tong, Y.; Yang, Q. Leaf morphology, photosynthetic performance, chlorophyll fluorescence, stomatal development of lettuce (Lactuca sativa L.) exposed to different ratios of red light to blue light. Front. Plant Sci. 2016, 7, 250. [CrossRef] [PubMed]

37. Lin, C. Phototropin blue light receptors and light—induced movement response in plants. Sci. Stke 2002, 118, pe5. [CrossRef] [PubMed]

38. Schroeder, J.I.; Allen, G.J.; Hugouvieux, V.; Kwak, J.M.; Waner, D. Guard cell signal transduction. Annu. Rev. Plant Physiol. Plant Mol. Biol. 2001, 52, 627-658. [CrossRef] [PubMed]

39. Shimazaki, K.I.; Doi, M.; Assmann, S.M.; Kinoshita, T. Light regulation of stomatal movement. Annu. Rev. Plant Biol. 2007, 58, 219-247. [CrossRef]

40. Rosenqvist, E. Light acclimation maintains the redox state of the PS II electron accepter QA within a narrow range over a broad range of light intensities. Photosynth. Res. 2002, 70, 299-310. [CrossRef]

41. Heo, J.W.; Kang, D.H.; Bang, H.S.; Hong, S.G.; Chun, C.; Kang, K.K. Early growth, pigmentation, protein content, and phenylalanine ammonia-lyase activity of red colored lettuces grown under different lighting condition. Korean J. Hort. Sci. Technol. 2012, 30, 6-12.

42. Quail, P.H. Photosensory perception and signaling in plant cells: New paradigms. Curr. Opin. Cell Biol. 2002, 14, 180-188. [CrossRef]

43. Wang, H.; Ma, L.G.; Li, J.M.; Zhao, H.Y.; Deng, X.W. Direct interaction of Arabidopsis cryptochromes with COP1 in light control development. Science 2001, 294, 154-158. [CrossRef] [PubMed]

44. Martinez-Garcia, J.F.; Huq, E.; Quail, P.H. Direct targeting of light signals to a promoter element-bound transcription factor. Science 2000, 288, 859-863. [PubMed] 
45. Hoenecke, M.E.; Bula, R.J.; Tibbitts, T.W. Importance of blue photon levels for lettuce seedlings grown under red light emitting diodes. HortScience 1992, 27, 427-430. [CrossRef] [PubMed]

46. Dougher, T.A.O.; Bugbee, B. Long term blue light effects on the histology of lettuce and soybean leaves and stem. J. Am. Soc. Hort. Sci. 2004, 129, 467-472. [CrossRef]

47. Samuoliene, G.; Sirtautas, R.; Brazaityte, A.; Sakalauskaite, J.; Sakalauskiene, S.; Duchovskis, P. The impact of red and blue light-emitting diode illumination on radish physiological indices. Cent. Eur. J. Biol. 2011, 6, 821-828. [CrossRef]

48. Hernandez, R.; Kubota, C. Physiological responses of cucumber seedlings under different blue and red photon flux ratios using LEDs. Environ. Exp. Bot. 2016, 121, 66-74. [CrossRef]

49. Kang, W.H.; Park, J.S.; Park, K.S.; Son, J.E. Leaf photosynthetic rate, growth, and morphology of lettuce under different fractions of red, blue, and green light from light-emitting diodes (LEDs). Hortic. Environ. Biotechnol. 2016, 57, 573. [CrossRef]

50. Chatterjee, M.; Sharma, P.; Khurana, J.P. Cryptochrome 1 from Brassica napus is up-regulated by blue light and controls hypocotyl/stem growth and anthocyanin accumulation. Plant Physiol. 2006, 141, 61-74. [CrossRef] [PubMed]

51. Metallo, R.M.; Kopsell, D.A.; Sams, C.E.; Bumgarner, N.R. Influence of blue/red vs. white LED light treatments on biomass, shoot morphology, and quality parameters of hydroponically grown kale. Sci. Hortic. 2018, 235, 189-197. [CrossRef]

52. Ouzounis, T.; Frette, X.; Rosenqvist, E.; Ottosen, C.O. Spectral effects of supplementary lighting on the secondary metabolites in roses, chrysanthemums, and campanulas. J. Plant Physiol. 2014, 171, 1491-1499. [CrossRef] [PubMed]

53. Kim, H.M.; Kang, J.H.; Jeong, B.R.; Hwang, S.J. Light quality and photoperiod affect growth of sowthistle (Ixeris dentata Nakai) in a closed-type plant production system. Korean J. Hort. Sci. Technol. 2016, 34, 67-76. [CrossRef]

54. Lin, K.H.; Huang, M.Y.; Huang, W.D.; Hsu, M.H.; Yang, Z.W.; Yang, C.M. The effect of red, blue and white light emitting diodes on the growth, development and edible quality of hydroponically grown lettuce (Lactusa sativa L. var. capitata). Sci. Hortic. 2013, 150, 86-91. [CrossRef]

55. Li, H.; Tang, C.; Xu, Z.; Liu, X.; Han, X. Effect of different light sources on the growth of non-heading Chinese cabbage (Brassica campestris L.). J. Agr. Sci. 2012, 4, 262-273. [CrossRef]

56. Saebo, A.; Krekling, T.; Appelgren, M. Light quality affects photosynthesis and leaf anatomy of brich plantlets in vitro. Plant Cell Tiss. Organ Cult. 1995, 41, 177-185. [CrossRef]

57. Li, H.; Tang, C.; Xu, Z. The effect of different light qualities on rape seed (Bassica napus L.) plantlet growth and morphogenesis in vitro. Sci. Hortic. 2013, 150, 117-124. [CrossRef]

58. Poffenroth, M.; Green, D.B.; Tallman, G. Sugar concentration in guard cells of Vicia faba illuminated with red or blue light. Plant Physiol. 1992, 98, 1460-1471. [CrossRef]

59. Yagi, K.; Hamada, K.; Hirata, K.; Miyamoto, K.; Miura, Y.; Akano, T.; Fukatu, K.; Ikuta, Y.; Nakamura, H.K. Stimulatory effect of red light on starch accumulation in a marine green alga, Chlamydomonas sp. strain MGA161. Appl. Biochem. Biotech. 1994, 45, 225-232. [CrossRef]

60. Cheng, J.; Fan, P.; Liang, Z.; Wang, Y.; Nie, N.; Li, W.; Li, S. Accumulation of end products in source leaves affects photosynthetic rate in peach via alteration of stomatal conductance and photosynthetic efficiency. J. Am. Soc. Hort. Sci. 2009, 134, 667-676. [CrossRef]

61. Ma, G.; Zang, L.; Kato, M.; Yamawaki, K.; Kiriiwa, Y.; Yahata, M.; Ikoma, Y.; Matsumoto, H. Effect of blue light and red LED light irradiation on $\beta$-cryptoxanthin accumulation in the flavedo of citrus fruits. J. Agr. Food Chem. 2012, 60, 197-201. [CrossRef]

62. Bukhov, N.G.; Drozdova, I.S.; Bondar, V.V.; Mokronosov, A.T. Blue, red and blueplus red light control of chlorophyll content and CO2gas exchange in barleyleaves: Quantitative description of the effects of light quality and fluence rate. Physiol. Plant. 1992, 85, 632-638. [CrossRef]

63. Evans, J.R. Acclimation by the thylakoid membranes to growth irradiance and the partitioning of nitrogen between soluble and thylakoid proteins. Aust. J. Plant Physiol. 1988, 15, 93-106. [CrossRef]

64. Yu, X.; Liu, H.; Klejnot, J.; Lin, C. The Cryptochrome Blue Light Receptors; The Arabidopsis Book; ASPB: Rockville, MD, USA, 2010. 
65. Stutte, G.W.; Edney, S.L.; Newsham, G.J. Photoregulation of Anthoycyanin Production in Red Leaf Lettuce with Blue LEDs is Affected by Timing and Leaf Age. In Proceedings of the 36th Annual Meeting of the Plant Growth Regulation Society of America, North Carolina, CA, USA, 2-6 August 2009; pp. 125-130.

66. Bian, Z.H.; Yang, Q.C.; Liu, W.K. Effect of light quality on the accumulation of phytochemcials in vegetables produced in controlled environments: A review. J. Sci. Food Agric. 2013, 95, 869-877. [CrossRef] [PubMed]

67. Park, J.S.; Chung, M.G.; Kim, J.B.; Hahn, B.S.; Kim, J.B.; Bae, S.C.; Roh, K.H.; Kim, Y.H.; Cheon, C.I.; Sung, M.K.; et al. Genes up-regulated during red coloration in UVB irradiated lettuce leaves. Plant Cell Rep. 2007, 26, 507-516. [CrossRef] [PubMed]

68. Awad, M.A.; Patricia, S.; Wagenmakers, P.S.; de Jager, A. Effects of light on flavonoid and chlorogenic acid levels in the skin of Jona gold apples. Sci. Hortic. 2001, 88, 289-298. [CrossRef]

69. Giliberto, L.; Perrotta, G.; Pallara, P.; Weller, J.L.; Fraser, P.D.; Bramley, P.M.; Fiore, A.; Tavazza, M.; Giuliano, G. Manipulation of the blue light photoreceptor cryptochrome-2 in tomato affects vegetative development, flowering time and fruit antioxidant content. Plant Physiol. 2005, 137, 199-208. [CrossRef] [PubMed]

70. Narukawa, M.; Watanable, K.; Inoue, Y. Light-induced root hair formation in lettuce (Lactusasativa L.cv. Grand Rapids) roots at low PH is brought by chlorogenic acid synthesis and sugar. J. Plant Res. 2010, 123, 789-799. [CrossRef]

(C) 2020 by the authors. Licensee MDPI, Basel, Switzerland. This article is an open access article distributed under the terms and conditions of the Creative Commons Attribution (CC BY) license (http://creativecommons.org/licenses/by/4.0/). 